\title{
Role of Reactive Oxygen in Bile Salt Stimulation of Colonic Epithelial Proliferation
}

\author{
Patricia A. Craven, James Pfanstiel, and Frederick R. DeRubertis \\ Department of Medicine, Veterans Administration Medical Center, \\ and School of Medicine, University of Pittsburgh, Pittsburgh, Pennsylvania 15240
}

\begin{abstract}
Our previous studies had suggested a link between bile salt stimulation of colonic epithelial proliferation and the release and oxygenation of arachidonate via the lipoxygenase pathway. In the present study, we examined the role of reactive oxygen versus end products of arachidonate metabolism via the cyclooxygenase and lipoxygenase pathways in bile salt stimulation of rat colonic epithelial proliferation. Intracolonic instillation of $5 \mathrm{mM}$ deoxycholate increased mucosal ornithine decarboxylase activity and $\left[{ }^{3}\right.$ H]thymidine incorporation into DNA. Responses to deoxycholate were abolished by the superoxide dismutase mimetic CuII (3,5 diisopropylsalicylic acid) 2 (CuDIPS), and by phenidone or esculetin, which inhibit both lipoxygenase and cyclooxygenase activities. By contrast, indomethacin potentiated the response. Phenidone and esculetin suppressed deoxycholate-induced increases in prostaglandin $\mathrm{E}_{2}\left(\mathrm{PGE}_{2}\right)$, leukotriene $\mathrm{B}_{4}\left(\mathrm{LTB}_{4}\right)$, and 5, 12, and 15-hydroxyeicosatetraenoic acid (HETE), whereas CuDIPS had no effect. Indomethacin suppressed only PGE 2 . Deoxycholate (0.5-5 mM) increased superoxide dismutase sensitive chemiluminescence $\mathbf{2 - 1 0}$-fold and stimulated superoxide production as measured by cytochrome $c$ reduction in colonic mucosal scrapings or crypt epithelium. Bile salt-induced increases in chemiluminescence were abolished by CuDIPS, phenidone, and esculetin, but not by indomethacin. Intracolonic generation of reactive oxygen by xanthine-xanthine oxidase increased colonic mucosal ornithine decarboxylase activity and $\left.{ }^{3} \mathbf{H}\right]$ thymidine incorporation into DNA approximately twofold. These effects were abolished by superoxide dismutase. The findings support a key role for reactive oxygen, rather than more distal products of either the lipoxygenase or cyclooxygenase pathways, in the stimulation of colonic mucosal proliferation by bile salts.
\end{abstract}

\section{Introduction}

Previous studies from our own (1) and other laboratories (2, 3) have demonstrated that bile salts increase ornithine decarboxylase activity $(O D C)^{1}$ and stimulate DNA synthesis in rat colonic

Address reprint requests to Dr. DeRubertis, VA Medical Center, University Drive C., Pittsburgh, PA 15240.

Received for publication 13 May 1985 and in revised form 19 November 1985.

1. Abbreviations used in this paper: $\mathrm{CL}$, chemiluminescence; CuDIPS, bis (3,5-diisopropylsalicylato) $(O, O)$ copper(II); DIPS, diisopropylsalicylic acid; DOC, deoxycholate; HETE, hydroxyeicosatetraenoic acid; HPLC, high pressure liquid chromatography; KRBG, Krebs-Ringer bicarbonate buffer; $\mathrm{LTB}_{4}$, leukotriene $\mathrm{B}_{4}$; ODC, ornithine decarboxylase activity; PG, prostaglandin; TdR, thymidine.

The Journal of Clinical Investigation, Inc.

Volume 77, March 1986, 850-859 epithelium. The ability of bile salts to increase the proliferative activity of colonic epithelium is associated with bile salt-induced release of arachidonate from colon and the conversion of arachidonate to prostaglandins (PGs) and lipoxygenase products (1). Phenidone, an antioxidant that blocks both cyclooxygenase and lipoxygenase activities, suppresses bile salt-induced increases in colonic proliferative activity and inhibits colonic prostaglandin $\mathrm{E}_{2}\left(\mathrm{PGE}_{2}\right)$ and 12-hydroxy-5,8,10,14-eicosatetraenoic acid (12-HETE) production (1). By contrast, indomethacin, which suppresses cyclooxygenase but not lipoxygenase product formation, stimulates basal proliferative activity of colonic epithelium and potentiates this response to bile salts (1). These findings had suggested a role for release of arachidonate and its subsequent oxygenation in the stimulation of the proliferative activity of colonic epithelium by bile salts. Our earlier studies with indomethacin indicated that end products of the cyclooxygenase pathway were not the mediators of bile salt-induced increases in proliferative activity. However, they did not delineate the potential role of reactive intermediates of arachidonate metabolism generated via either the cyclooxygenase or lipoxygenase pathways versus end products of the lipoxygenase pathway in the stimulation of colonic epithelial proliferation by bile salts.

Superoxide $\left(\mathrm{O}_{2}^{-}\right)$and its sequential reduction products hydrogen peroxide $\left(\mathrm{H}_{2} \mathrm{O}_{2}\right)$ and the hydroxy radical $(\mathrm{OH} \cdot)$ are formed as a result of cellular utilization of $\mathrm{O}_{2}$, including the oxidation of arachidonate via either the cyclooxygenase or lipoxygenase systems (4-7). In the present study, we examined the role of reactive oxygen species, as measured by superoxide dismutase sensitive chemiluminescence (CL) and cytochrome $c$ reduction in the mediation of bile salt actions to stimulate colonic mucosal ODC and tritiated thymidine $\left[{ }^{3} \mathrm{H}\right] \mathrm{TdR}$ incorporation into DNA. Thus, we assessed (a) the action of bile salts on $\mathrm{CL}$ and cytochrome $c$ reduction in colonic mucosal scrapings and colonic crypt epithelium; $(b)$ the actions of bile salts on the production of leukotriene $\mathrm{B}_{4}\left(\mathrm{LTB}_{4}\right), 5,12$, and 15-HETE, and $\mathrm{PGE}_{2}$ in colonic mucosal scrapings; (c) the effects of bis $[(3,5-$ diisopropylsalicylato) $(O, O)]$ copper (II) (CuDIPS), a small lipophilic complex with superoxide dismutase activity (8), of two structurally dissimilar lipoxygenase inhibitors, phenidone and esculetin, and of indomethacin on basal and bile salt-induced increases in colonic mucosal ODC, and $\left[{ }^{3} \mathrm{H}\right] \mathrm{TdR}$ incorporation into DNA; and $(d)$ the effects of these same inhibitors on bile salt-induced increases in CL and the production of $\mathrm{LTB}_{4}$, HETEs, and $\mathrm{PGE}_{2}$. Our results support a key role for reactive oxygen species, likely generated as a consequence of bile saltinduced phospholipid breakdown with release of arachidonate or other membrane lipid moieties, in the mediation of the stimulatory action of bile salts on the proliferative activity of colonic mucosa. They indicate that the end products of the cyclooxygenase and lipoxygenase pathways do not mediate bile salt effects on proliferative activity. 


\section{Methods}

Determination of $O D C$ and $\left[{ }^{3} H\right] T d R$ incorporation into colonic mucosal $D N A$. Female Sprague-Dawley rats (Zivic-Miller Laboratories, Pittsburgh, PA) were fasted for $8 \mathrm{~h}$ before surgery and throughout the study period. Rats were anesthetized with pentobarbital $(50 \mathrm{mg} / \mathrm{kg}$ i.p.), and the colon intestine was exposed through a midline abdominal incision. Test agents were administered intracolonically as previously described in detail (1). Briefly, a 20-gauge needle was inserted into the lumen of the large intestine at the cecal junction. The large intestine was thoroughly flushed free of visible luminal contents with $0.9 \%$ saline that had been warmed to $37^{\circ} \mathrm{C}$ and equilibrated with $100 \% \mathrm{O}_{2}$. A ligature was then placed externally at the anorectal junction to prevent escape of test solutions. Saline $(2 \mathrm{ml})$, or a solution of test agents in $2 \mathrm{ml}$ of saline $\left(37^{\circ} \mathrm{C}\right)$ was instilled into the lumen of the distal colon. In some studies, as indicated in the text, 30 min after insertion of the first test solution, a second instillation of $2 \mathrm{ml}$ of saline or a second test agent in $2 \mathrm{ml}$ of saline $\left(37^{\circ} \mathrm{C}\right)$ was made. The needle puncture site was then oversewn. The abdominal incision was closed with wound clips. At $4 \mathrm{~h}$, control and experimental rats were again anesthetized with pentobarbital, $50 \mathrm{mg} / \mathrm{kg}$ i.p. For determination of ODC, the distal colons were resected from the colonic flexure to $1 \mathrm{~cm}$ above the anal orifice. For determination of $\left[{ }^{3} \mathrm{H}\right] \mathrm{TdR}$ incorporation into DNA the contents of the colon were removed by gentle lavage with saline and the incision was again closed with wound clips. $\left[{ }^{3} \mathrm{H}\right] \mathrm{TdR}$ $(100 \mu \mathrm{Ci} / \mathrm{kg})$ was injected intraperitoneally $22 \mathrm{~h}$ after the bile salt or saline instillation had been made. Rats were killed $2 \mathrm{~h}$ after the injection of $\left[{ }^{3} \mathrm{H}\right] \mathrm{TdR}$. Distal colons were excised and placed in saline at $4^{\circ} \mathrm{C}$. The mucosa was scraped and DNA content was extracted, counted, and assayed as previously described $(1,9)$.

Preparation of mucosal scrapings. Rats were fasted for $8 \mathrm{~h}$ and anesthetized with phenobarbital $(50 \mathrm{mg} / \mathrm{kg}$ i.p.). The large intestine was exposed and flushed free of luminal contents as described above. The thoracic cavity was then opened and the inferior vena cava was cut below the inferior mesenteric vein. Krebs-Ringer bicarbonate buffer (KRBG) $\left(95 \% \mathrm{O}_{2}, 5 \% \mathrm{CO}_{2}\right)$ was then infused through the left ventricle for $5 \mathrm{~min}$ at $30 \mathrm{ml} / \mathrm{min}$ until the colon was thoroughly blanched to reduce contamination of the mucosal scrapings with blood cells. The distal colon was then removed and the mucosal surface was scraped with a stainless steel spatula. The mucosa $(100 \mathrm{mg}$ wet weight $/ \mathrm{ml})$ was suspended in KRBG. The resulting suspension was used for determination of $C L$ and in vitro production of $\mathrm{PGE}_{2}$ and lipoxygenase products as described below.

Isolation of colonic crypts. Colonic crypts were isolated from rat colon by a method previously described for crypt isolation in the mouse colon (10). Briefly, the large intestine was exposed and flushed free of luminal contents as described above. The colon was then perfused through the left ventricle with $30 \mathrm{mM}$ EDTA in $\mathrm{Ca}^{2+}-\mathrm{Mg}^{2+}$ free $\mathrm{KRBG}, 95 \% \mathrm{O}_{2}$, $5 \% \mathrm{CO}_{2}$ as described in detail above. The colon was then excised, gently everted on a rod, secured with surgical thread, and attached to a Buchler vibrating assembly. The everted colon was immersed in KRBG, 95\% $\mathrm{O}_{2}, 5 \% \mathrm{CO}_{2}$ and vibrated at 60 cycles/s for $5 \mathrm{~min}$. The isolated tissue was washed three times in cold KRBG and suspended in KRBG for CL measurements. The procedure yielded small sheets of epithelium and single crypt units. Contamination by underlying nonepithelial elements was determined by light microscopy.

Measurement of $C L$. CL was measured as described previously (11) in a Packard beta scintillation counter (model 3380, Packard Instrument Co., Downers Grove, IL) maintained at room temperature and operated in the out of coincidence mode (gain 100\%; window A to $\infty$; discriminators $0-1,000$ ). The standard incubation mixture contained $0.15 \mathrm{M}$ $\mathrm{NaCl}, 0.05 \mathrm{M}$ phosphate, $0.04 \mathrm{mM}$ luminol (pH 7.6). This solution was placed in a dark-adapted vial brought to $37^{\circ} \mathrm{C}$ and background $\mathrm{CL}$ (usually $\leq 2,000 \mathrm{cpm} / 0.2 \mathrm{~min}$ ) determined at 18 -s intervals for $5 \mathrm{~min}$. Unless otherwise indicated, an aliquot of mucosal scrapings (routinely $0.2-0.5$ $\mathrm{mg}$ protein) was then added to the incubation vial and the counting rate monitored for $0.2 \mathrm{~min}$ at 18 -s intervals for $5 \mathrm{~min}$. An addition of bile salts was then made and measurement of $C L$ continued for $5 \mathrm{~min}$. All test agents were kept in the dark and equilibrated at $37^{\circ} \mathrm{C}$ before addition to the vial. Measurements were performed in a darkened room. Where indicated in the text, mucosal scrapings were preexposed to test agents for $10 \mathrm{~min}$ before addition to the incubation vial. All values shown represent peak values obtained $10 \mathrm{~s}$ after addition of tissue or bile salts and have been corrected for the background CL obtained with the phosphatebuffered saline plus luminol.

Measurement of $\mathrm{O}_{2}^{-\cdot}$ production by cytochrome c reduction. Unless otherwise indicated, $\mathrm{O}_{2}^{-\cdot}$ production from xanthine plus xanthine oxidase was measured by the cytochrome $c$ reduction assay (12). Assays routinely contained $75 \mu \mathrm{M}$ cytochrome $c, 1 \mathrm{mM}$ phosphate buffer, pH 7.4, $1 \mathrm{mM}$ xanthine, $5 \mathrm{mU}$ xanthine oxidase and, when indicated, $20 \mu \mathrm{g} / \mathrm{ml}$ superoxide dismutase. Cytochrome $c$ reduction was followed at $500 \mathrm{~nm}$ in a cuvette maintained at $37^{\circ} \mathrm{C}$. Results were calculated using an extinction coefficient of $21 \times 10^{3} \mathrm{M}^{-1} \mathrm{~cm}^{-1}$.

Assays containing colonic crypt epithelium were conducted as described above except that acetylated cytochrome $c$ was employed. Acetylation was performed as previously described (13) except that the molar ratio of acetic anhydride to cytochrome $c$ was reduced to 50 . The percent acetylation as determined by the dinitrophenol method (14) was 53\%. Catalase, $50 \mu \mathrm{g} / \mathrm{ml}$, was included in all assays that contained acetylated cytochrome $c(13)$. The production of $\mathrm{O}_{2}^{-\cdot}$ from colonic crypts was linear with time (0-2.5 $\mathrm{min})$ and crypt protein concentration $(2-6 \mathrm{mg})$ under the conditions employed.

Incubation and extraction of mucosal scrapings for the determination of $P G E_{2}, L T B_{4}$, and 5, 12, and 15-HETE. Mucosal scrapings (20-30 $\mathrm{mg}$ protein) were prepared from thoroughly perfused distal colons as described above. Scrapings were incubated in $5 \mathrm{ml} \mathrm{KRBG,} \mathrm{95 \%} \mathrm{O}_{2}, 5 \%$ $\mathrm{CO}_{2}$ at $37^{\circ} \mathrm{C}$ in the presence and absence of test agents as described in the text. Incubations were conducted in duplicate. At the end of the incubation, a trace amount $(0.025 \mu \mathrm{Ci})$ of $\left[{ }^{3} \mathrm{H}\right] \mathrm{LTB}_{4},\left[{ }^{3} \mathrm{H}\right] \mathrm{PGE}_{2},\left[{ }^{3} \mathrm{H}\right]$ 12-HETE, $\left[{ }^{3} \mathrm{H}\right]$ 5-HETE, and $\left[{ }^{3} \mathrm{H}\right]$ 15-HETE were added to the incubates, and the cells plus media were extracted in a homogenizing tube with $1.5 \mathrm{ml}$ of $25 \mathrm{mM} \mathrm{HCl}$ plus $4.5 \mathrm{ml}$ ether as previously described (15). All solvents employed for the extraction contained $50 \mu \mathrm{g} / \mathrm{ml}$ butylated hydroxtoluene (BHT) to retard autooxidation of unsaturated fatty acids. The ether layer was removed and the aqueous layer was reextracted with $6 \mathrm{ml}$ of ether followed by $6 \mathrm{ml}$ of ethyl acetate. The ether layers were combined and evaporated to $4 \mathrm{ml}$ under $\mathrm{N}_{2}$ and $0.25 \mathrm{~g}$ of unisil was added. The extracts were vortexed, the ether phase was removed, and the silicic acid was washed with $4 \mathrm{ml}$ of $\mathrm{CHCl}_{3} / \mathrm{CH}_{3} \mathrm{OH}$ 9:1. The silicic acid removes phospholipids from the lipid extracts (15). The ether, ethyl acetate, and $\mathrm{CHCl}_{3} / \mathrm{CH}_{3} \mathrm{OH}$ layers were then combined, evaporated to dryness, resuspended with sonication ( $10 \mathrm{~s}$ on ice) in $\mathrm{CH}_{3} \mathrm{OH} / \mathrm{H}_{2} \mathrm{O} /$ acetic acid 65:35:0.01, and filtered through a 0.5- $\mu \mathrm{m}$ Millipore FH filter (Millipore Corp., Bedford, MA) for high pressure liquid chromatography (HPLC).

HPLC purification of $P G E_{2}, L T B_{4}$, and 5, 12, and 15-HETE. The sample was applied to a Waters $\mu$ Bondapak $\mathrm{C} 18$ column (Waters Associates, Milford, MA). The mobile phase was $\mathrm{CH}_{3} \mathrm{OH} / \mathrm{H}_{2} \mathrm{O}$ /acetic acid 65:35:0.01 (16). Flow rate was $1 \mathrm{ml} / \mathrm{min}$ and fractions were collected and counted at 1 -min intervals. The relevant retention times were $\mathrm{PGE}_{2}$, $8 \mathrm{~min}$; $\mathrm{LTB}_{4}, 20 \mathrm{~min}$; 15-HETE, $48 \mathrm{~min}$; 12-HETE, $55 \mathrm{~min}$, and 5HETE, $64 \mathrm{~min}$. HPLC fractions were stored at $-20^{\circ} \mathrm{C}$ and assayed within $2 \mathrm{wk}$. On the day of assay, the peak tubes were combined, a 1-ml aliquot removed, evaporated to dryness, and resuspended in $0.5 \mathrm{ml}$ of $0.9 \%$ $\mathrm{NaCl}, 0.01 \mathrm{M}$ EDTA, $0.3 \%$ bovine gamma-globulin, $0.005 \%$ Triton $\mathrm{X}-100$, and $0.05 \%$ sodium azide in $50 \mathrm{mM}$ phosphate buffer, $\mathrm{pH} 6.8$, with 10-s sonication on ice. An aliquot of the sample was counted for recovery and the results were corrected based on the recovery of the internal standards. Recoveries of $\left[{ }^{3} \mathrm{H}\right] \mathrm{PGE}_{2},\left[{ }^{3} \mathrm{H}\right] \mathrm{LTB}_{4},\left[{ }^{3} \mathrm{H}\right] 5,12$, and 15-HETE were not significantly different from each other and usually varied between $20 \%$ and $50 \%$.

Radioimmunoassay of $P G E_{2}, L T B_{4}$, and 5, 12, and 15-HETE. All determinations of $\mathrm{PGE}_{2}, \mathrm{LTB}_{4}$, and 5, 12, and 15-HETE were performed following purification of extracts of colonic mucosa by HPLC. PGE was determined using reagents obtained from New England Nuclear (Boston, MA). 5, 12, and 15-HETE were determined using reagents obtained from Seragen, Inc. (Boston, MA). LTB $_{4}$ radioimmunoassay kits 
were purchased from Amersham Corp. (Arlington Heights, IL). Standard curves were plotted as logit-log functions from $0.25-25 \mathrm{pg}$ of $\mathrm{PGE}_{2}$; 0.010-2 ng of 5, 12, and 15-HETE, and $12.5-400 \mathrm{pg}$ of LTB $_{4}$. Crossreactivity of arachidonate and 5,12 , and 15 -HETE was $\leq 0.5 \%$. Crossreactivity of $\mathrm{PGE}_{2}$ and arachidonate in the 5,12, or 15-HETE assays was not $>0.1 \%$. Cross-reactivity of 5,12 , or 15 -HETE in each others assays was $<0.1 \%$. Under the conditions used, the radioimmunoassay values obtained varied linearly over a 10 -fold range of dilutions.

Determination of $O D C$ activity. Rats were killed $4 \mathrm{~h}$ after intraluminal instillation of bile salts or saline. The mucosal surface of the distal colon was scraped and $150 \mathrm{mg}$ wet weight was homogenized in $1 \mathrm{ml}$ of $50 \mathrm{mM}$ sodium phosphate, $\mathrm{pH} 7.4$, which contained $0.1 \mathrm{mM}$ pyridoxal phosphate and $0.1 \mathrm{mM}$ EDTA. Homogenates were centrifuged at $38,000 \mathrm{~g}$ for 20 min and the supernatants were assayed immediately. Enzyme activity was determined from the release of ${ }^{14} \mathrm{CO}_{2}$ from DL- $\left[1-{ }^{14} \mathrm{C}\right]$ ornithine as previously described $(1,17)$. Briefly, reaction mixtures contained 0.02 $\mathrm{mM}$ pyridoxal phosphate, $4 \mathrm{mM}$ dithiothreitol, $1 \mathrm{mM}$ EDTA, $0.4 \mathrm{mM}$ L-ornithine, $40 \mathrm{mM}$ sodium phosphate (pH 7.2), $100 \mu$ l of the colonic mucosal soluble fraction $\left(\simeq 100 \mu \mathrm{g}\right.$ of protein) and $0.5 \mu \mathrm{Ci}$ of $\mathrm{DL}-\left[1-{ }^{14} \mathrm{C}\right]$ ornithine in a final volume of $0.25 \mathrm{ml}$. Assays were done in duplicate. Blanks contained buffer alone or the heated $\left(95^{\circ} \mathrm{C}\right.$ for $\left.10 \mathrm{~min}\right)$ soluble fraction. Results were corrected for the blank value obtained. ODC was linear with time for $60 \mathrm{~min}$ with 20-200 $\mu \mathrm{g}$ of protein under all conditions of study.

Preparation of CUDIPS. CuDIPS was prepared as previously described (18). Briefly, $5 \mathrm{~g}$ of 3,5 diisopropyl salicylic acid was dissolved in $100 \mathrm{ml}$ of $\mathrm{H}_{2} \mathrm{O}$ by addition of $50 \% \mathrm{NaOH}$, filtered, and adjusted to $\mathrm{pH} 8-9$. This solution was added to $\mathrm{CuCl}_{2}$ dihydrate solution $(0.59 \mathrm{~g} / 300 \mathrm{ml}$ $\mathrm{H}_{2} \mathrm{O}$ ) slowly with continuous stirring. The brown precipitate that formed was collected on a Buchner funnel and redissolved in ether. The green crystals of CuDIPS that formed from ether were collected and dried at $125^{\circ} \mathrm{C}$ for $3 \mathrm{~h}$ at which time they appear brown and melt at $142-144^{\circ} \mathrm{C}$.

Materials. Reagents and antisera for radioimmunoassay of 5, 12, and 15-HETE were obtained from Seragen, Inc. DL $\left[1-{ }^{14} \mathrm{C}\right]$ Ornithine (30-55 mCi/mmol), [ $\left.{ }^{3} \mathrm{H}\right] 5-, 12-$, and $15-\operatorname{HETE}(30-100 \mathrm{Ci} / \mathrm{mmol})$, and reagents for radioimmunoassay of $\mathrm{PGE}_{2}$ were obtained from New England Nuclear. $\mathrm{LTB}_{4}$ radioimmunoassay kits were obtained from Amersham Corp. Arachidonic acid (99\%) was obtained from Nu-Chek Prep, Inc. (Elysian, $\mathrm{MN}$ ). $\mathrm{CuCl}_{2}$, cupric acetate, and 3,5 diisopropyl salicylic acid (DIPS) were obtained from Aldrich Chemical Co. (Milwaukee, WI). Phenidone, esculetin, deoxycholate (DOC), cholate, chenodeoxycholate, superoxide dismutase, 5-amino 2,3 dihydro-1,4-phthalazinedione (luminol), allopurinol, 7,8 benzoflavone, and xanthine oxidase were obtained from Sigma Chemical Co. (St. Louis, MO). SKF-525A was the generous gift of Hoffmann-LaRoche, Inc., (Nutley, NJ). The sources of all other reagents have been previously reported (1).

Statistics. Statistical significance of differences between mean values was determined by the $t$ test for unpaired data. For ODC and $\left[{ }^{3} \mathrm{H}\right] \mathrm{Tdr}$ incorporation into DNA, studies were conducted on six rats in each experimental group. Between 8 and 12 rats could be studied on any given day. Experiments were thus repeated until the indicated number of rats in each group had been studied. For the purposes of statistical analysis, the average of replicate determinations for any parameter from a single rat colon was entered as a single value $(\mathrm{df}=10)$. In vitro incubations for determination of $\mathrm{PGE}_{2}, \mathrm{LTB}_{4}$, and 5, 12, and 15-HETE production and $C L$ were performed in duplicate. Experiments were performed three times. The average values of duplicate determinations of $\mathrm{PGE}_{2}, \mathrm{LTB}_{4}, 5,12$, and 15-HETE, and CL from each experiment were entered as a single value for the purposes of statistical analysis $(\mathrm{df}=4$ comparing any two experimental conditions by Student's independent $t$ test).

\section{Results}

$C L$. As illustrated in Fig. 1, addition of colonic mucosal scrapings to phosphate-buffered saline plus luminol produced an immediate increase in CL that declined progressively over the next 5

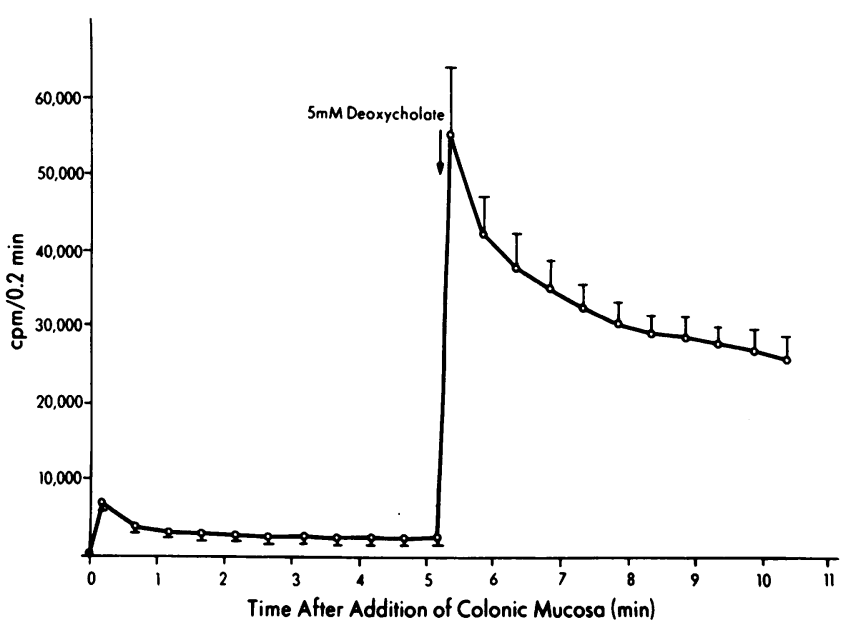

Figure 1. Time course of changes in CL of colonic mucosal scrapings in the presence and absence of DOC. At time 0 , a 100- $\mu$ l aliquot of colonic mucosal scrapings suspended in $\mathrm{KRBG}, 95 \% \mathrm{O}_{2}, 5 \% \mathrm{CO}_{2}$ ( $0.5 \mathrm{mg}$ protein) was added to dark-adapted scintillation vials which contained $1 \mathrm{ml}$ of $0.15 \mathrm{M} \mathrm{NaCl}, 0.05 \mathrm{M}$ phosphate, $0.04 \mathrm{M}$ luminol, $\mathrm{pH}$ 7.6. The measurement of counts per minute/ $0.2 \mathrm{~min}$ was begun $10 \mathrm{~s}$ after addition of colonic mucosa and monitored at 18-s intervals for $5 \mathrm{~min}$. DOC ( $5 \mathrm{mM}$ ) (arrow) was then added, and counts per minute $/ 0.2 \mathrm{~min}$ were monitored for an additional $5 \mathrm{~min}$ at 18 -s intervals. Results shown have been corrected for background CL, determined before addition of tissue by counting the vial containing phosphatebuffered saline plus luminol for $5 \mathrm{~min}$ at 18-s intervals before addition of tissue. Results shown are means \pm standard error of duplicate determinations pooled from three separate experiments.

min but did not reach baseline levels. Subsequent addition of DOC to a final concentration of $5 \mathrm{mM}$ caused a 20-fold increase in $\mathrm{CL}$ within $10 \mathrm{~s}$ compared to that observed with tissue alone. $\mathrm{CL}$ declined progressively during the next $5 \mathrm{~min}$ but did not reach baseline.

As illustrated in Fig. 2, basal and DOC-induced increases in CL varied linearly with added mucosal protein between 100 and $600 \mu \mathrm{g}$. No further increase in CL was observed with or without DOC when the added protein was increased to $1.25 \mathrm{mg}$. Moreover, addition of superoxide dismutase $(10 \mu \mathrm{g} / \mathrm{ml})$ to the suspension abolished basal and DOC-induced increases in CL, consistent with a role for $\mathrm{O}_{2}^{-}$in the mediation of the changes in CL.

Colonic mucosal scrapings represent a heterogeneous preparation which normally contains several different cell types, including leukocytes. The latter could contribute to the $\mathrm{CL}$ observed. In order to gain insight into the cellular source of $\mathrm{CL}$ observed, we isolated colonic crypts using a previously published preparative procedure (10). The crypt preparation was composed of small epithelial sheets and single crypt units. $~ 95 \%$ of the cells were epithelial cells, $3-4 \%$ were lymphocytes, and $1 \%$ was neutrophils. CL was examined in three separate crypt preparations with $0.2-0.3 \mathrm{mg}$ of protein per incubation. $\mathrm{CL}$ with the crypt preparation was quantitatively similar to that observed with colonic mucosal scrapings and was markedly suppressed by superoxide dismutase (-DOC, 5,569 \pm 601 ; +DOC, $63,092 \pm 7,587 ; \mathrm{DOC}+$ superoxide dismutase, $2,874 \pm 352, \mathrm{cpm} /$ $0.2 \mathrm{~min} \pm \mathrm{SE}$ ). Analogous to findings with colonic mucosal scrapings, $C L$ of colonic crypts varied linearly with added protein between 100 and $600 \mu \mathrm{g}$. These results suggest that the CL ob- 


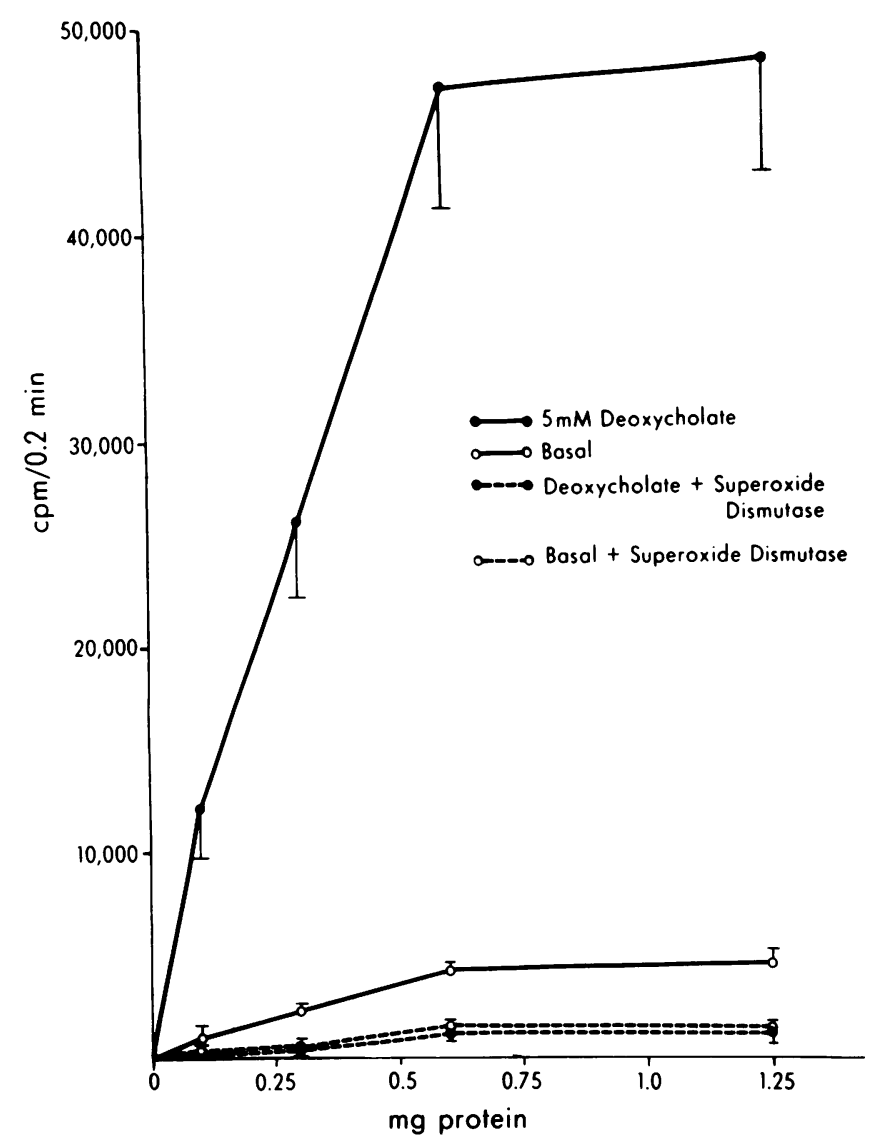

Figure 2. Relationship between colonic mucosal protein and basal and $\mathrm{DOC}$-induced increases in $\mathrm{CL}$ in the presence and absence of superoxide dismutase. Studies were conducted as described in Fig. 1. Colonic mucosal protein was varied between 0.1 and $1.25 \mathrm{mg}$. Superoxide dismutase $(20 \mu \mathrm{g} / \mathrm{ml})$ was added to some of the vials before tissue addition (dashed lines). Basal and DOC-stimulated rates were determined in the same incubates. Where indicated, DOC was added to colonic mucosal incubates 5 min after addition of tissue. Results shown are means \pm standard error of duplicate counting rates from three separate experiments obtained $10 \mathrm{~s}$ after addition of colonic mucosa $(0)$ or $\mathrm{DOC}(\bullet)$ to the vial.

served in colonic mucosal scrapings is largely derived from epithelial cells. In other studies (not shown), CL of colonic mucosal scrapings was not influenced by $10^{-7} \mathrm{M} \mathrm{N}$-formyl-L-methionylL-leucyl phenylalanine, a known stimulus of $\mathrm{O}_{2}^{-}$production in neutrophils (19). Thus, an important role for neutrophils as a cellular source of the CL that we observed in colonic mucosa seems unlikely.

DOC could influence $\mathrm{O}_{2}^{-\cdot}$ accumulation by stimulating production of $\mathrm{O}_{2}^{-\cdot}$ or by inhibiting endogenous superoxide dismutase activity. Mixtures of xanthine plus xanthine oxidase generate CL which is suppressed by superoxide dismutase (8). In order to distinguish between increased production and decreased catabolism of $\mathrm{O}_{2}^{-}$in the expression of DOC effects on $\mathrm{CL}$, we examined the concentration response relationship between superoxide dismutase and xanthine-xanthine oxidase-induced CL in the presence and absence of DOC. Xanthine (1 $\mathrm{mM})$ and xanthine oxidase $(0.5 \mathrm{U})$ were mixed in a scintillation vial with $0.15 \mathrm{M} \mathrm{NaCl}, 0.05 \mathrm{M}$ phosphate, $\mathrm{pH} 7.6$, containing $0.04 \mathrm{mM}$ luminol, and counts per minute $/ 0.2 \mathrm{~min}$ determined $10 \mathrm{~s}$ later as described above for determination of $\mathrm{CL}$ in colonic mucosa. Significant (25-80\%) suppressive effects of superoxide dismutase on $\mathrm{CL}$ induced by xanthine plus xanthine oxidase were observed with $0.1-1 \mu \mathrm{g} / \mathrm{ml}$ of superoxide dismutase and complete inhibition with $10 \mu \mathrm{g} / \mathrm{ml}$ of this enzyme. The concentration response relationship between superoxide dismutase and xanthine oxidase induced $\mathrm{CL}$ was not influenced by $5 \mathrm{mM}$ DOC (not shown). Thus, the effect of DOC to increase CL in colonic mucosa could not be explained by a direct suppression of superoxide dismutase activity.

Fig. 3 illustrates the concentration response relationships between DOC, chenodeoxycholate or cholate, and CL in isolated colonic mucosa. The first significant increase in CL was observed at $0.5 \mathrm{mM}$ DOC. As illustrated, $\mathrm{CL}$ increased progressively as the concentration of DOC was increased to $25 \mathrm{mM}$. Raising the concentration of DOC to $50 \mathrm{mM}$ did not result in CL which was greater than that observed at $25 \mathrm{mM}$ deoxycholate (not shown). The concentration response relationship between DOC and $C L$ in vitro is analogous to that previously reported between DOC and colonic mucosal ODC when mucosa was exposed to DOC in vivo by intracolonic instillation (1). As is also illustrated in Fig. 3, chenodeoxycholate and cholate increased CL in colonic mucosa, but were much less effective than DOC in this regard. The minimum effective dose of chenodeoxycholate was $5 \mathrm{mM}$ and of cholate, $10 \mathrm{mM}$. Optimal six- and four-fold increases in CL were observed at $25 \mathrm{mM}$ chenodeoxycholate and cholate respectively.

Previous results from our laboratory (1) suggested that the ability of DOC to increase ODC and stimulate $\left[{ }^{3} \mathrm{H}\right] \mathrm{TdR}$ incorporation into DNA was mediated by enhanced release of arachidonate from tissue phospholipids and its oxygenation via the lipoxygenase pathway. Accordingly, we examined the effects of exogenous arachidonate on CL. As shown in Table I, addition of sufficient exogenous arachidonate to mucosal scrapings to yield a final concentration of $500 \mu \mathrm{M}$ resulted in an increase in $\mathrm{CL}$ which was similar to that seen with $5 \mathrm{mM}$ DOC. Increasing the concentration of arachidonate to $1.5 \mathrm{mM}$ further increased $\mathrm{CL}$ by 20 -fold compared to that seen in colonic mucosa not

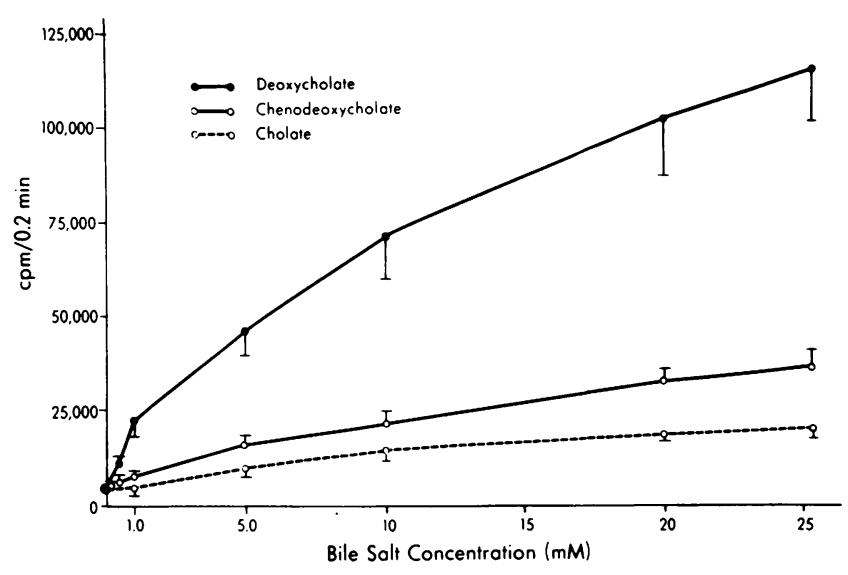

Figure 3. Concentration response relationship between bile salts and $\mathrm{CL}$ in colonic mucosa. Studies were conducted as described in Fig. 1. Where indicated DOC $(\bullet-\bullet)$, chenodeoxycholate $(0-0)$, or cholate ( 0 -..- $)$ was added to colonic mucosal scrapings $(0.5 \mathrm{mg}$ protein) in phosphate-buffered saline to give the final indicated concentrations. The results shown are means \pm standard error of duplicate determinations from three separate experiments. Counting rates were determined $10 \mathrm{~s}$ after addition of bile salt to the incubates. 
Table I. Effects of Arachidonate and DOC on CL of Colonic Mucosa

\begin{tabular}{lc}
\hline Test agents & Rate \\
\hline & $c p m / 0.2 \mathrm{~min}$ \\
None & $4,856 \pm 312$ \\
$5 \mathrm{mM} \mathrm{DOC}$ & $49,563 \pm 7,630$ \\
$25 \mathrm{mM} \mathrm{DOC}$ & $118,020 \pm 14,202$ \\
$500 \mu \mathrm{M}$ arachidonate & $52,219 \pm 7,359$ \\
$1.5 \mathrm{mM}$ arachidonate & $129,536 \pm 15,620$ \\
$25 \mathrm{mM}$ DOC $+1.5 \mathrm{mM}$ arachidonate & $124,641 \pm 17,359$ \\
\hline
\end{tabular}

Studies were conducted as described in the legend to Fig 1. Where indicated, the counting rate shown was determined $10 \mathrm{~s}$ after addition of colonic mucosa (none) or test agents to the incubates. Results are means \pm SE of duplicate (DOC or arachidonate) or 10 (none) determinations from three separate experiments. Basal counting rates did not differ among the experimental conditions and were combined.

exposed to arachidonate. Raising the concentration of arachidonate further did not result in an increase in CL compared to that seen at $1.5 \mathrm{mM}$ arachidonate (not shown). The increase in CL with $1.5 \mathrm{mM}$ arachidonate was analogous to that observed with an optimal concentration of DOC (25 mM). Moreover, combined addition of $25 \mathrm{mM} \mathrm{DOC}$ and $1.5 \mathrm{mM}$ arachidonate did not further increase $\mathrm{CL}$ above that seen with either agent alone.

Effects of test agents on $C L$. We assessed the effects of several inhibitors of known pathways for $\mathrm{O}_{2}^{-}$production (20) on basal and DOC-induced increases in CL of colonic mucosa. As illustrated in Table II, allopurinol, an inhibitor of xanthine oxidase activity (21), $\mathrm{KCN}$, an inhibitor of mitochondrial cytochrome oxidase activity (22), benzoflavone or SKF-525A, inhibitors of colonic microsomal cytochrome P-450 (23), failed to alter basal or DOC-induced increases in CL of colonic mucosa when employed at concentrations that have previously been shown to

Table II. Effects of Various Inhibitors of

Cellular Superoxide Production on Basal and DOC-induced Increases in CL of Colonic Mucosa

\begin{tabular}{lll}
\hline & \multicolumn{2}{l}{ Rate } \\
\cline { 2 - 3 } Initial additions & Basal & DOC \\
\hline & $c p m / 0.2 \mathrm{~min}$ & $c p m / 0.2 \mathrm{~min}$ \\
None & $4,723 \pm 561$ & $53,629 \pm 7,214$ \\
$25 \mathrm{mM}$ allopurinol & $4,812 \pm 632$ & $51,790 \pm 6,319$ \\
$1 \mathrm{mM} \mathrm{KCN}$ & $5,173 \pm 712$ & $47,328 \pm 8,192$ \\
$50 \mu$ M benzoflavone & $4,769 \pm 581$ & $49,627 \pm 7,562$ \\
$2 \mathrm{mM} \mathrm{SKF}-525 \mathrm{~A}$ & $4,921 \pm 604$ & $48,992 \pm 6,134$ \\
\hline
\end{tabular}

Studies were conducted as described in the legend to Fig. 1. Where indicated under initial additions, test agents were added to the colonic mucosa $10 \mathrm{~min}$ before addition of the tissue to the scintillation vial. Basal and DOC-stimulated counting rates were determined in the same incubates. Where indicated, DOC was added to colonic mucosal incubates $5 \mathrm{~min}$ after addition of tissue. Results shown are means \pm SE of duplicate counting rates from three separate experiments obtained $10 \mathrm{~s}$ after addition of colonic mucosa or DOC to the vial. suppress these oxidative pathways in intestine and other tissues (21-23).

Table III compares the effects of agents that have been reported to suppress arachidonate oxygenation via the cyclooxygenase and lipoxygenase pathway on basal and DOC-induced increases in colonic mucosal CL. Because antioxidant inhibitors of arachidonate oxidation may also suppress CL by scavenging $\mathrm{O}_{2}^{-}$, the effects of these same inhibitors on CL produced by the $\mathrm{O}_{2}^{-}$-generating system, xanthine-xanthine oxidase was examined. As illustrated in Table III, esculetin $(100 \mu \mathrm{M})$ and phenidone $(100 \mu \mathrm{M})$, antioxidants that have been shown to inhibit both cyclooxygenase and lipoxygenase activity $(1,24,25)$, suppressed basal and DOC-induced increases in CL of colonic mucosa by $40-50 \%$. Raising the concentration of esculetin or phenidone to $500 \mu \mathrm{M}$ further suppressed CL to $20 \%$ of the value seen in the absence of either inhibitor, and abolished the stimulatory effect of DOC on this parameter. As is also shown in Table III, indomethacin, an inhibitor of cyclooxygenase but not lipoxygenase activity in colon and other tissues $(1,26)$, was without effect on basal or DOC-induced increases in CL. The ability of antioxidant inhibitors of both cyclooxygenase and lipoxygenase activity such as phenidone to suppress DOC-induced increases in $\mathrm{CL}$ of colonic mucosa and the failure of indomethacin, a selective inhibitor of cyclooxygenase activity, to inhibit $\mathrm{CL}$ is analogous to the previously observed actions of these same agents on bile salt-induced increases in ODC and $\left[{ }^{3} \mathrm{H}\right] \mathrm{TdR}$ incorpo-

Table III. Effects of Esculetin, Phenidone, and Indomethacin on Basal CL and Increases Induced by Xanthine Oxidase or DOC in Colonic Mucosa

\begin{tabular}{|c|c|c|c|}
\hline \multirow[b]{2}{*}{ Initial additions } & \multicolumn{3}{|l|}{ Rate } \\
\hline & $-\mathrm{DOC}$ & $+\mathrm{DOC}$ & +Xanthine oxidase \\
\hline & $\mathrm{cpm} / 0.2 \mathrm{~min}$ & $\mathrm{cpm} / 0.2 \mathrm{~min}$ & $\mathrm{cpm} / 0.2 \mathrm{~min}$ \\
\hline None & $5,126 \pm 622$ & $45,971 \pm 5,971$ & $41,324 \pm 4,726$ \\
\hline \multicolumn{4}{|l|}{ Esculetin } \\
\hline $100 \mu \mathrm{M}$ & $2,634 \pm 168^{*}$ & $28,293 \pm 2,912^{*}$ & $21,693 \pm 3,241^{*}$ \\
\hline $500 \mu \mathrm{M}$ & $1,024 \pm 168^{*}$ & $1,193 \pm 162^{*}$ & $932 \pm 123^{*}$ \\
\hline \multicolumn{4}{|l|}{ Phenidone } \\
\hline $25 \mu \mathrm{M}$ & $3,251 \pm 514^{*}$ & $30,652 \pm 4,019^{*}$ & $27,210 \pm 3,214^{*}$ \\
\hline $100 \mu \mathrm{M}$ & $1,987 \pm 242^{*}$ & $2,049 \pm 262^{*}$ & $4,456 \pm 572^{*}$ \\
\hline \multicolumn{4}{|l|}{ Indomethacin } \\
\hline $100 \mu \mathrm{M}$ & $5,210 \pm 684$ & $47,963 \pm 5,912$ & $44,722 \pm 6,231$ \\
\hline $1 \mathrm{mM}$ & $5,342 \pm 731$ & $52,697 \pm 5,341$ & $49,284 \pm 5,271$ \\
\hline
\end{tabular}

Studies were conducted as described in the legend to Fig. 1. Where indicated, the colonic mucosa was preincubated for $10 \mathrm{~min}$ with test agents shown under initial additions. Separate colonic mucosal incubates were used for the determination of (a) basal and DOC-stimulated rates or (b) basal and xanthine, xanthine oxidase-stimulated rates. Where indicated, DOC or xanthine plus xanthine oxidase were added to the scintillation vials $5 \mathrm{~min}$ after addition of tissue. Basal counting rates did not differ before addition of DOC or xanthine oxidase in incubations containing the same concentration of esculetin, phenidone or indomethacin and were combined. Counting rates shown are means $\pm S E$ of duplicate (DOC or xanthine oxidase) or four determinations from three separate experiments obtained $10 \mathrm{~s}$ after addition of colonic mucosa, DOC $(5 \mathrm{mM})$, or xanthine $(1 \mathrm{mM})$ plus xanthine oxidase $(0.1 \mathrm{U})$ to the scintillation vial.

* $P<0.01$ compared to corresponding value in the absence of an initial addition. 
ration into mucosal DNA in vivo (1). As is illustrated in Table III, $\mathrm{Cl}$ induced by xanthine plus xanthine oxidase was also suppressed by esculetin and phenidone, when these inhibitors were tested at concentrations that resulted in suppression of DOCinduced increases in $\mathrm{CL}$ of colonic mucosa. Moreover, analogous to results obtained with colonic mucosa, indomethacin did not inhibit $\mathrm{CL}$ induced by xanthine plus xanthine oxidase. These studies suggest that, in addition to their actions as lipoxygenase and cyclooxygenase inhibitors, phenidone and esculetin may suppress basal or bile salt induced increases in CL by scavenging $\mathrm{O}_{2}^{-\cdot}$ or other forms of active oxygen.

Phenidone and luminol have previously been shown to serve as cooxidative substrates in the peroxidative reduction of fatty acid hydroperoxides $(27,28)$. The peroxidative cooxidation of luminol results in CL. Accordingly, it is possible that lipid peroxides produced after addition of DOC to the colonic mucosa participate in the cooxidation of luminol to a chemiluminescent moiety. Further, phenidone might suppress CL by substituting for luminol as a cooxidative substrate rather than by scavenging $\mathrm{O}_{2}^{-} \cdot$. It seems unlikely that peroxidative cooxidation of luminol plays an important role in bile salt-induced increases in CL because the cooxidation reaction has been reported to be unaffected by superoxide dismutase (27) under conditions that abolish DOC-induced increases in CL of colonic mucosa. Nevertheless, to assess further the role of $\mathrm{O}_{2}^{-}$or other activated forms of oxygen in the mediation of DOC-induced increases in CL of colonic mucosa and the possibility that phenidone and esculetin inhibit $\mathrm{CL}$ in colonic mucosa by scavenging $\mathrm{O}_{2}^{-}$or other reactive forms of oxygen, we employed a second assay procedure for determination of $\mathrm{O}_{2}^{-}$that did not involve the use of luminol. The generation of $\mathrm{O}_{2}^{-\cdot}$ from xanthine plus xanthine oxidase was monitored by ferricytochrome $c$ reduction as previously described in detail (12). Addition of superoxide dismutase (20 $\mu \mathrm{g} / \mathrm{ml})$, phenidone $(500 \mu \mathrm{M})$, or esculetin $(500 \mu \mathrm{M})$ abolished cytochrome $c$ reduction (not shown). In other studies (not shown) uric acid production from xanthine plus xanthine oxidase was assessed as previously described (29). In contrast to the ability of phenidone and esculetin to suppress $\mathrm{O}_{2}^{-}$production from xanthine plus xanthine oxidase, these antioxidants did not suppress uric acid production. These results imply that esculetin and phenidone scavenge $\mathrm{O}_{2}^{-}$rather than inhibit xanthine oxidase activity.

As illustrated in Table IV, CuDIPS $(500 \mu \mathrm{M}$ to $1 \mathrm{mM})$ suppressed (30-100\%) basal and DOC-induced increases in CL in colonic mucosal scrapings. CuDIPS also inhibited CL induced by xanthine oxidase (Table IV) or arachidonate when tested over the same concentration range. By contrast, neither cupric acetate $(1 \mathrm{mM})$ or DIPS $(1 \mathrm{mM})$ had any influence on CL under the conditions employed in Table IV.

Measurement of $\mathrm{O}_{2}^{-\cdot}$ production in colonic crypts by cytochrome c reduction. $\mathrm{CL}$ is a nonspecific measure of $\mathrm{O}_{2}^{-}$production (30). Accordingly, we employed superoxide dismutase inhibitable cytochrome $c$ reduction to assess $\mathrm{O}_{2}^{-\cdot}$ production in isolated colonic crypts. Acetylated cytochrome $c$ was employed in these assays to reduce the enzymatic reduction and/or oxidation of cytochrome $c$ by cellular enzymes released after addition of DOC to the colonic crypts as previously described (13). Addition of catalase $(50 \mu \mathrm{g} / \mathrm{ml})$ to the assay was also essential to prevent oxidation of cytochrome $c$ by $\mathrm{H}_{2} \mathrm{O}_{2}$ as previously described (13). As illustrated in Table V, significant cytochrome $c$ reduction was observed in colonic crypt epithelium incubated in the absence of DOC. This low level of cytochrome $c$ reduction
Table IV. Effects of CuDIPS on Basal CL or Increases Induced by DOC or Xanthine Oxidase in Colonic Mucosa

\begin{tabular}{llll}
\hline & Rate & & \\
\cline { 2 - 4 } & $-\mathrm{DOC}$ & $+\mathrm{DOC}$ & + Xanthine oxidase \\
\hline & $c p m / 0.2 \mathrm{~min}$ & $c p m / 0.2 \mathrm{~min}$ & $c p m / 0.2 \mathrm{~min}$ \\
$\begin{array}{l}\text { Initial additions } \\
\text { None }\end{array}$ & & & \\
$\begin{array}{l}\text { CuDIPS } \\
500 \mu \mathrm{M}\end{array}$ & $4,362 \pm 582$ & $56,321 \pm 728^{*}$ & $49,563 \pm 7,261^{*}$ \\
$\quad 1 \mathrm{mM}$ & $1,872 \pm 256 \ddagger$ & $2,132 \pm 287 \ddagger$ & $1,731 \pm 252 \ddagger$ \\
\hline
\end{tabular}

Studies were conducted as described in the legend to Fig. 1. Where indicated, colonic mucosa was exposed to CuDIPS at the final indicated concentration for $10 \mathrm{~min}$ before addition of tissue to the vial. Separate incubates were used for the determination of (a) basal and DOCstimulated rates or (b) basal and xanthine oxidase-stimulated rates. Where indicated, DOC or xanthine plus xanthine oxidase was added to the vials 5 min after addition of tissue. Basal counting rates did not differ before addition of DOC or xanthine oxidase in incubations containing the same concentration of CuDIPS and were combined. Counting rates shown are means \pm SE of duplicate (DOC or xanthine oxidase) or four determinations from three separate experiments. * $P<0.01$ compared to corresponding value in the absence of DOC or xanthine oxidase.

$\ddagger P<0.01$ compared to corresponding value in the absence of CuDIPS.

was not influenced by superoxide dismutase and was therefore not attributable to $\mathrm{O}_{2}^{-}$production. Addition of DOC to the colonic crypt preparation stimulated the production of $\mathrm{O}_{2}^{-\cdot}$ to a level of $2.9 \mathrm{nmol} / \mathrm{min}$ per $2.5 \mathrm{mg}$ protein. The increase in cytochrome $c$ reduction with DOC was abolished by inclusion of superoxide dismutase in the assay cuvette. Accordingly, the calculated level of DOC-stimulated superoxide dismutase inhibitable cytochrome $c$ reduction was $1.0 \mathrm{nmol} / \mathrm{min} \cdot \mathrm{mg}$ protein. The authenticity of the assay was verified by the ability to quantitatively measure known amounts of $\mathrm{O}_{2}^{-}$generated in the colonic crypt preparation by addition of xanthine plus xanthine oxidase. Thus, as is also illustrated in Table $\mathrm{V}, \mathrm{O}_{2}^{-}$production by xanthine plus xanthine oxidase in the presence of colonic

Table V. Stimulation of Superoxide Production by DOC in Colonic Crypts

\begin{tabular}{lll}
\hline & \multicolumn{2}{l}{ Production } \\
\cline { 2 - 3 } & - SOD & +SOD \\
\hline & $n m o l / m i n$ & $n m o l / m i n$ \\
Colonic crypts & $0.41 \pm 0.03$ & $0.42 \pm 0.04$ \\
+DOC, $5 \mathrm{mM}$ & $2.9 \pm 0.02$ & $0.40 \pm 0.04$ \\
+Xanthine-xanthine oxidase & $5.2 \pm 0.06$ & $0.41 \pm 0.03$ \\
Xanthine-xanthine oxidase & $4.6 \pm 0.04$ & N.D. \\
& & \\
\end{tabular}

$\mathrm{O}_{2}^{-\cdot}$ production was assessed by cytochrome $c$ reduction as described in the Methods. Where indicated, assays contained $2.5 \mathrm{mg}$ of colonic crypt protein and $5 \mathrm{mU}$ of xanthine oxidase activity. Results shown are means $\pm \mathrm{SE}$ of duplicate determinations on three separate preparations of colonic crypts. ND, not determined. 
crypts was identical to that measured in the absence of colonic crypts.

Cyclooxygenase and lipoxygenase product formation. Table VI illustrates the effects of esculetin, phenidone, and indomethacin on basal and DOC-induced increases in $\mathrm{PGE}_{2}, \mathrm{LTB}_{4}, 5$ HETE, 12-HETE, and 15-HETE accumulation in colonic mucosal incubates. $\mathrm{PGE}_{2}$ was used as an index of prostaglandin synthetic activity in these studies. As shown, incubation of colonic mucosa for $60 \mathrm{~min}$ in KRBG in the absence of exogenous arachidonate led to significant production of $\mathrm{PGE}_{2}, \mathrm{LTB}_{4}$, and 5,12 , and 15-HETE, as measured by radioimmunoassay of HPLC purified fractions of the incubates. Inclusion of DOC in the incubation medium significantly increased the production of all of these arachidonate metabolites. As shown, esculetin and phenidone $(100 \mu \mathrm{M})$ suppressed basal and DOC-induced increases in all of the arachidonate metabolites measured. In other experiments (not shown), $\mathrm{PGE}_{2}, 5,12$, and 15-HETE, and $\mathrm{LTB}_{4}$ were not detectable in incubates containing $500 \mu \mathrm{M}$ phenidone or esculetin. By contrast, $100 \mu \mathrm{M}$ indomethacin suppressed $\mathrm{PGE}_{2}$ production, but enhanced both basal accumulation of $\mathrm{LTB}_{4}$ and 5,12 , and 15-HETE and the increases in these products induced by DOC. As is also illustrated in Table V, when tested at 5 or $25 \mathrm{mM}$, CuDIPS had no significant effect on basal accumulation of $\mathrm{PGE}_{2}, \mathrm{LTB}_{4}, 5,12$, or 15-HETE, or the increases in these products induced by DOC.

Ornithine decarboxylase and $\left[{ }^{3} \mathrm{H}\right] \mathrm{TdR}$ incorporation into $D N A$. As previously reported (1), intracolonic instillation of DOC $(10 \mu \mathrm{mol}, 5 \mathrm{mM})$ increases colonic mucosal ODC activity and $\left[{ }^{3} \mathrm{H}\right] \mathrm{TdR}$ incorporation into DNA. These effects are both abolished by pretreatment of rats with phenidone (1). By contrast, indomethacin enhanced these actions of DOC (1). As illustrated in Table VII, intracolonic instillation of $50 \mu \mathrm{mol}(25 \mathrm{mM})$ of esculetin was without effect on basal ODC or $\left[{ }^{3} \mathrm{H}\right] \mathrm{TdR}$ incorporation into DNA, but abolished DOC-induced increases in these parameters. These effects of esculetin are entirely analogous to those previously reported for phenidone (1).

As shown in Table VIII, intracolonic instillation of CuDIPS $(50 \mu \mathrm{mol}, 25 \mathrm{mM})$ had no effect on basal ODC or $\left[{ }^{3} \mathrm{H}\right] \mathrm{TdR}$ incorporation into DNA. However, CuDIPS abolished DOCinduced increases in these two parameters (Table VIII). By contrast, neither cupric acetate nor DIPS had any effect on basal or DOC induced increases in ODC or $\left[{ }^{3} \mathrm{H}\right] \mathrm{TdR}$ incorporation into DNA when tested at the same concentration as CuDIPS (not shown).

To assess more directly the influence of $\mathrm{O}_{2}^{-\cdot}$ on colonic mucosal ODC and $\left[{ }^{3} \mathrm{H}\right] \mathrm{TdR}$ incorporation into DNA, we examined the effects of intracolonic instillation of xanthine plus xanthine oxidase on these parameters. As illustrated in Table IX, intracolonic instillation of xanthine plus xanthine oxidase increased ODC threefold at $4 \mathrm{~h}$ and $\left[{ }^{3} \mathrm{H}\right] \mathrm{TdR}$ incorporation into DNA twofold at $24 \mathrm{~h}$. Inclusion of superoxide dismutase in the $\mathrm{O}_{2}^{-}$. generating system abolished the effects of the $\mathrm{O}_{2}^{-}$generating system on both of these parameters (Table IX). As is also shown, heat inactivation of superoxide dismutase abolished its suppressive effect on ODC and $\left[{ }^{3} \mathrm{H}\right] \mathrm{TdR}$ incorporation into DNA, supporting the specificity of action of this enzyme on $\mathrm{O}_{2}^{-}$.

Table VI. Effects of Esculetin, Phenidone, Indomethacin, and CUDIPS on Basal and DOC-induced Increases in PGE $2, L T B_{4}$, and 5, 12, and 15-HETE Accumulation in Colonic Mucosa

\begin{tabular}{|c|c|c|c|c|c|c|c|c|c|c|}
\hline \multirow[b]{2}{*}{ Initial additions } & \multicolumn{2}{|l|}{$\mathrm{PGE}_{2}$} & \multicolumn{2}{|l|}{$\mathrm{LTB}_{4}$} & \multicolumn{2}{|l|}{ 5-HETE } & \multicolumn{2}{|l|}{ 12-HETE } & \multicolumn{2}{|l|}{ 15-HETE } \\
\hline & $-\mathrm{DOC}$ & $+\mathrm{DOC}$ & $-\mathrm{DOC}$ & $+\mathrm{DOC}$ & $-\mathrm{DOC}$ & $+\mathrm{DOC}$ & $-\mathrm{DOC}$ & $+\mathrm{DOC}$ & $-\mathrm{DOC}$ & $+D O C$ \\
\hline & \multicolumn{10}{|c|}{$n g / m g$ protein } \\
\hline \multirow[t]{2}{*}{ None } & 1.1 & $2.3 \ddagger$ & 1.8 & $3.9 \ddagger$ & 2.5 & $5.2 \ddagger$ & 1.5 & $2.8 \ddagger$ & 0.69 & $1.1 \ddagger$ \\
\hline & \pm 0.1 & \pm 0.3 & \pm 0.3 & \pm 0.5 & \pm 0.3 & \pm 0.6 & \pm 0.2 & \pm 0.4 & \pm 0.8 & \pm 0.2 \\
\hline Esculetin, & $0.44^{*}$ & $0.72^{*}$ & $0.59^{*}$ & $1.6^{*}$ & $1.1^{*}$ & $2.4^{*}$ & $0.84^{*}$ & $1.3^{*}$ & $0.43^{*}$ & $0.67^{*}$ \\
\hline $100 \mu \mathrm{M}$ & \pm 0.06 & \pm 0.09 & \pm 0.07 & \pm 0.2 & \pm 0.2 & \pm 0.3 & \pm 0.09 & \pm 0.2 & \pm 0.05 & \pm 0.08 \\
\hline Phenidone, & $0.31^{*}$ & $0.79 \ddagger$ & $0.45^{*}$ & $0.87^{*} \ddagger$ & $0.82^{*}$ & $3.1^{*} \ddagger$ & $0.76^{*}$ & $1.1^{*} \ddagger$ & $0.51^{*}$ & $0.84^{*} \ddagger$ \\
\hline $100 \mu \mathrm{M}$ & \pm 0.04 & \pm 0.09 & \pm 0.06 & \pm 0.01 & \pm 0.01 & \pm 0.5 & \pm 0.09 & \pm 0.2 & \pm 0.01 & \pm 0.09 \\
\hline \multicolumn{11}{|l|}{ Indomethacin } \\
\hline \multirow[t]{2}{*}{$25 \mu \mathrm{M}$} & $0.47^{*}$ & $0.93^{*} \ddagger$ & 1.9 & $3.7 \ddagger$ & 2.8 & $5.4 \ddagger$ & 1.3 & $2.7 \ddagger$ & 0.81 & $1.3 \ddagger$ \\
\hline & \pm 0.06 & \pm 0.1 & \pm 0.3 & \pm 0.5 & \pm 0.3 & \pm 0.6 & \pm 0.1 & \pm 0.4 & \pm 0.09 & \pm 0.2 \\
\hline \multirow[t]{2}{*}{$100 \mu \mathrm{M}$} & n.d. & n.d. & $2.6^{*}$ & $5.4^{*} \ddagger$ & $3.9^{*}$ & $7.8^{*} \ddagger$ & $2.8^{*}$ & $4.4^{*} \ddagger$ & $1.9^{*}$ & $2.8^{*} \ddagger$ \\
\hline & & & \pm 0.3 & \pm 1.0 & \pm 0.5 & \pm 0.8 & \pm 0.4 & \pm 0.5 & \pm 0.3 & \pm 0.5 \\
\hline \multicolumn{11}{|l|}{ CuDIPS } \\
\hline \multirow[t]{2}{*}{$5 \mathrm{mM}$} & 0.92 & 2.1 & 1.7 & 3.6 & 2.4 & 5.9 & 1.1 & 2.4 & 0.72 & 1.4 \\
\hline & \pm 0.1 & \pm 0.3 & \pm 0.2 & \pm 0.5 & \pm 0.3 & \pm 0.7 & \pm 0.2 & \pm 0.3 & \pm 0.08 & \pm 0.2 \\
\hline \multirow[t]{2}{*}{$25 \mathrm{mM}$} & 0.72 & 1.8 & 1.5 & 3.9 & 2.5 & 6.3 & 1.4 & 2.8 & 0.65 & 1.5 \\
\hline & \pm 0.09 & \pm 0.3 & \pm 0.1 & \pm 0.6 & \pm 0.2 & \pm 0.9 & \pm 0.2 & \pm 0.5 & \pm 0.08 & \pm 0.3 \\
\hline
\end{tabular}

Colonic mucosal scrapings ( $1.2 \mathrm{~g}$ wet $\mathrm{wt}$ ) were incubated in $5 \mathrm{ml} \mathrm{KRBG}, 95 \% \mathrm{O}_{2}, 5 \% \mathrm{CO}_{2}$ at $37^{\circ} \mathrm{C}$ for 10 min with test agents shown under initial additions. DOC was then added to give a final concentration of $5 \mathrm{mM}$ and the incubation continued for an additional 15 min. PGE 2 and lipoxygenase products were then extracted from the scrapings plus media, were then purified by HPLC and assayed by radioimmunoassay as described in Methods. Results shown are means $\pm \mathrm{SE}$ of duplicate determinations from three separate experiments. ${ }^{*} P<0.05$ compared to corresponding value in the absence of an initial addition. $¥ P<0.05$ compared to corresponding value in the absence of DOC. 
Table VII. Effects of Intracolonic Instillation of Esculetin on Basal and DOC-induced Increases in ODC and $\left[{ }^{3} \mathrm{H}\right]$ TdR Incorporation into DNA of Colonic Mucosa

\begin{tabular}{llll}
\hline Intracolonic instillation & & ODC & {$\left[{ }^{3} \mathrm{H}\right] \mathrm{TdR}$} \\
\hline & & $\begin{array}{l}\text { pmol CO } 2 / \mathrm{min} \cdot \mathrm{mg} \\
\text { protein }\end{array}$ & $d p m / \mu g$ DNA \\
No. 1 (time 0) & No. $2(30 \mathrm{~min})$ & & \\
Saline & Saline & $2.4 \pm 0.3$ & $11 \pm 1$ \\
Saline & DOC, $10 \mu \mathrm{mol}$ & $36 \pm 5^{*}$ & $29 \pm 4^{*}$ \\
Esculetin, $50 \mu \mathrm{mol}$ & Saline & $2.2 \pm 0.4$ & $12 \pm 2$ \\
Esculetin, $50 \mu \mathrm{mol}$ & DOC, $10 \mu \mathrm{mol}$ & $2.6 \pm 0.3 \ddagger$ & $10 \pm 1 \ddagger$ \\
& & & \\
\hline
\end{tabular}

At time $0,2 \mathrm{ml}$ of saline or esculetin dissolved in $2 \mathrm{ml}$ of saline ( 25 $\mathrm{mM}$ esculetin) was instilled intracolonically in rats as indicated. Controls received saline alone. At $30 \mathrm{~min}, 2 \mathrm{ml}$ of saline or $10 \mu \mathrm{mol}$ of $\mathrm{DOC}$ in saline (5 mM DOC) was instilled. For determination of ODC, rats were killed $4 \mathrm{~h}$ after exposure to DOC. $\left[{ }^{3} \mathrm{H}\right] \mathrm{TdR}$ incorporation into DNA was determined $24 \mathrm{~h}$ after exposure to DOC. Results shown are means $\pm \mathrm{SE}$ of duplicate determination on six rats $(\mathrm{df}=10)$.

* $P<0.01$ compared to corresponding value in rats receiving saline at time 0 and at $30 \mathrm{~min}$.

$\ddagger P<0.01$ compared to corresponding value in rats receiving saline at time 0 and $\mathrm{DOC}$ at $30 \mathrm{~min}$.

\section{Discussion}

The lipoxygenase-catalyzed peroxidation of unsaturated fatty acids (6), the synthesis of prostaglandins (7), and other pathways of cellular $\mathrm{O}_{2}$ utilization $(4,5)$ are often accompanied by the production of reactive oxygen species, including $\mathrm{O}_{2}^{--}$and its reduction products $\mathrm{H}_{2} \mathrm{O}_{2}$ and $\mathrm{HO} \cdot$. The results of the present study indicate that bile salt stimulation of ODC and the proliferative activity of colonic epithelium may be linked to enhanced generation of reactive oxygen species after bile salt-induced phospholipid breakdown. The relative effectiveness of bile salts to increase $\mathrm{CL}$ in colonic mucosa in vitro correlate well with

Table VIII. Effects of Intracolonic Instillation of CuDIPS on Basal and DOC-induced Increases in ODC and $\left[{ }^{3} H\right] T d R$ Incorporation into DNA of Colonic Mucosa

\begin{tabular}{lll}
\hline Intracolonic instillation & ODC & {$\left[{ }^{3} \mathrm{H}\right] \mathrm{TdR}$} \\
\hline pmol CO$/ \mathrm{mg}$ protein & $d p m / \mu g \mathrm{DNA}$
\end{tabular}

$\begin{array}{lllc}\text { No. 1 (time 0) } & \text { No. } 2(30 \mathrm{~min}) & & \\ \text { Saline } & \text { Saline } & 2.2 \pm 0.3 & 10 \pm 1 \\ \text { Saline } & \text { DOC, } 10 \mu \mathrm{mol} & 34 \pm 5^{*} & 27 \pm 4^{*} \\ \text { CuDIPS, } 50 \mu \mathrm{mol} & \text { Saline } & 2.3 \pm 0.2 & 9 \pm 1 \\ \text { CuDIPS, } 50 \mu \mathrm{mol} & \text { DOC, } 10 \mu \mathrm{mol} & 2.5 \pm 0.3 \ddagger & 11 \pm 2 \ddagger\end{array}$

At time $02 \mathrm{ml}$ of saline or CuDIPS suspended in saline $(25 \mathrm{mM}$ CuDIPS) was instilled intracolonically in rats as indicated. Controls received saline alone. At $30 \mathrm{~min}, 2 \mathrm{ml}$ of saline or $10 \mu \mathrm{mol}$ of DOC $(5 \mathrm{mM})$ in saline was distilled. For determination of ODC rats were sacrificed $4 \mathrm{~h}$ after exposure to DOC. $\left[{ }^{3} \mathrm{H}\right] \mathrm{TdR}$ incorporation into DNA was determined $24 \mathrm{~h}$ after exposure to DOC. Results shown are means \pm SE of duplicate determinations on six rats $(\mathrm{df}=10)$.

* $P<0.01$ compared to corresponding value in rats exposed to saline at time 0 and at $30 \mathrm{~min}$.

$\ddagger P<0.01$ compared to corresponding value in rats exposed to saline at time 0 and $\mathrm{DOC}$ at $30 \mathrm{~min}$.
Table IX. Effects of Intracolonic Instillation of Xanthine-Xanthine Oxidase with or without Superoxide Dismutase on Ornithine Decarboxylase Activity and $\left[{ }^{3} \mathrm{H}\right] \mathrm{TdR}$ Incorporation into DNA of Colonic Mucosa

\begin{tabular}{lll}
\hline Intracolonic instillation & ODC & $\left.{ }^{3} \mathrm{H}\right] \mathrm{TdR}$ \\
\hline & $\begin{array}{l}\text { pmol } \mathrm{CO}_{2} / \mathrm{min} \cdot \mathrm{mg} \\
\text { protein }\end{array}$ & $\mathrm{dpm} / \mu \mathrm{g}$ DNA \\
& $2.1 \pm 0.3$ & $10 \pm 2$ \\
$\begin{array}{l}\text { Saline } \\
\begin{array}{l}\text { Xanthine-xanthine oxidase } \\
\text { Xanthine-xanthine oxidase plus } \\
\quad \text { superoxide dismutase }\end{array}\end{array}$ & $6.8 \pm 0.9^{*}$ & $18 \pm 3^{*}$ \\
$\begin{array}{l}\text { Xanthine-xanthine oxidase plus } \\
\text { heat-treated superoxide } \\
\text { dismutase }\end{array}$ & $1.9 \pm 0.3$ & $12 \pm 1$ \\
\hline
\end{tabular}

Saline $(2 \mathrm{ml})$, xanthine $(10 \mathrm{mM})$-xanthine oxidase $(0.6 \mathrm{U})$ or xanthine-xanthine oxidase plus superoxide dismutase $(40 \mu \mathrm{g}$ in $2 \mathrm{ml}$ of saline) were instilled intrarectally as indicated. Where shown, superoxide dismutase was heat inactivated at $95^{\circ} \mathrm{C}$ for $10 \mathrm{~min}$. For determination of ODC, rats were sacrificed $4 \mathrm{~h}$ after exposure to test agents. $\left[{ }^{3} \mathrm{H}\right] \mathrm{TdR}$ incorporation into DNA was determined $24 \mathrm{~h}$ after exposure to test agents. Results shown are means $\pm \mathrm{SE}$ of duplicate determinations on six rat colons $(\mathrm{df}=10)$.

${ }^{*} P<0.01$ compared to corresponding value in control rats receiving saline alone.

their relative effectiveness as stimuli of arachidonate release in vitro and as stimuli of colonic mucosal proliferative activity in vivo (1). In this regard, it is notable that reactive oxygen species have also been implicated in the mediation of phorbol esterinduced increases in ODC and tumor promotion in a mouse skin model $(31,32)$.

However, in addition to stimulation of CL, exposure of colonic mucosa to bile salts results in increased accumulation of distal products of both the cyclooxygenase and lipoxygenase pathways. Phenidone and esculetin, which suppressed the actions of bile salts to stimulate $C L$ and epithelial proliferative activity, also inhibited colonic formation of $\mathrm{PGE}_{2}$ and several lipoxygenase products. Nevertheless, as previously reported (1), it is unlikely that the action of esculetin or phenidone to suppress $\mathrm{PGE}_{2}$ production by colon accounts for the ability of these agents to inhibit DOC-induced increases in the proliferative activity of colon epithelium. Thus, indomethacin, which selectively suppressed accumulation of prostaglandins relative to lipoxygenase products in colonic mucosa $(1,31)$, actually enhanced the basal proliferative activity of colon epithelium and potentiated the increases in proliferation induced by bile salts (1). Moreover, exogenous $\mathrm{PGE}_{2}$ and other PGs suppress DNA synthesis of colonic mucosa both in vitro (33) and in vivo (34). The ability of phenidone and esculetin to suppress bile salt-induced increases in colonic epithelial proliferative activity, the accumulation of lipoxygenase products, and the increase in CL was therefore consistent with a role for either distal lipoxygenase products or reactive oxygen species in the stimulation of epithelial proliferation by bile salts. Accordingly, in the present studies, we examined the role of reactive oxygen species in the expression of bile salt action under conditions that did not influence formation of more distal products of the lipoxygenase pathway. In these studies, we employed CuDIPS, a small lipophilic molecule with superoxide dismutase activity. CuDIPS has previously been shown to suppress phorbol ester-induced increases in CL, ODC, and tumor promotion in mouse skin and epidermal cells (31, 
32). However, in those studies, the influence of CuDIPS on the accumulation of PGs and lipoxygenase products was not assessed. Our present observations with CuDIPS strongly support a key role for reactive oxygen species, rather than more distal products of the lipoxygenase pathway, in the expression of bile salt actions on colonic proliferative activity. Thus, this agent suppressed bile salt-induced increases in $\mathrm{CL}$ and proliferative activity, but had no effect on bile salt-induced increases in distal lipoxygenase products.

A role for $\mathrm{O}_{2}^{-\cdot}$ or its reaction products in expression of the action of bile salts to increase proliferative activity was supported by the demonstration that direct intraluminal generation of $\mathrm{O}_{2}^{-} \cdot$ by xanthine oxidase increased $\mathrm{ODC}$ and stimulated $\left[{ }^{3} \mathrm{H}\right] \mathrm{TdR}$ incorporation into DNA of colonic mucosa in vivo. Moreover, in the present study low levels of $\mathrm{O}_{2}^{-\cdot}$ were shown to be produced by colonic crypts incubated in the presence of DOC. The DOCmediated production of $\mathrm{O}_{2}^{-}$was abolished by superoxide dismutase. The cytochrome $c$ reduction assay employed for these measurements is highly specific for $\mathrm{O}_{2}^{-}(12)$ and has been used extensively in studies of $\mathrm{O}_{2}^{-}$production in phagocytic cells (12). To our knowledge, only one other study, conducted in epidermal cells (35), has documented $\mathrm{O}_{2}^{-\cdot}$ production by the cytochrome $c$ assay in an intact nonphagocytic cell system. The difficulty in employing this assay in nonphagocytic cells is likely related to (a) lower levels of $\mathrm{O}_{2}^{-}$production, $(b)$ the presence of superoxide dismutase (36), and (c) the low sensitivity of cytochrome $c$ reduction compared to CL.

Several potential pathways exist for bile salt-induced increases in reactive oxygen production in colonic mucosa. Intestinal mucosa is known to contain xanthine oxidase activity (5). $\mathrm{O}_{2}^{-}$ formed as a result of xanthine oxidase action on hypoxanthine, produced during the breakdown of ATP, has been implicated in the mediation of postischemic tissue injury (5). However, in the present study, allopurinol, a potent inhibitor of xanthine oxidase (21), failed to suppress basal or bile salt-induced increases in CL. These results implied that colonic xanthine oxidase was not involved in bile salt action. Similarly, the failure of cyanide, an inhibitor of mitochondrial cytochrome oxidase activity (22) and of 7,8 benzoflavone and SKF-525A, inhibitors of colonic microsomal NADPH cytochrome $P-450$ reductase activity (23), to suppress basal or bile salt-induced increases in CL do not support a role for these cellular oxidases in the mediation of the observed changes in CL. A number of membrane perturbants, including phorbol esters and cis unsaturated fatty acids $(19,37-$ 41 ), stimulate the production of large amounts of $\mathrm{O}_{2}^{-}$in the phagocytic cells. The mechanism by which this occurs is not known, although it has been proposed that these stimulants activate protein kinase $C(42)$, disorder gellike regions in membranes (41), or are metabolized via lipoxygenase with the intermediate release of $\mathrm{O}_{2}^{-}(40)$. Several observations in colon supported a role for enhanced release of arachidonate in the mediation of bile salt-induced increases in reactive oxygen. Bile salts increase release of arachidonate from tissue lipid stores by stimulating phospholipase activity (1). Arachidonate per se may then act to increase reactive oxygen production, as has been recently suggested in studies of neutrophils (19). Alternatively, reactive oxygen may be generated during the oxidation of arachidonate via the cyclooxygenase (7) or lipoxygenase (6) pathways. In this regard, it should be emphasized that the failure of indomethacin to suppress DOC-induced increases in CL in colon does not rule out a role for arachidonate oxidation by the cyclooxygenase pathway in the mediation of bile salt $\mathrm{CL}$ response. The present and previous (1) studies provide evidence that end products of the cyclooxygenase and lipoxygenase pathways per se do not mediate the bile salt-induced increases in production of reactive oxygen or proliferative activity. However, they do not define the relative contributions of the cyclooxygenase and the lipoxygenase pathways of arachidonate oxygenation in the increases in reactive oxygen production induced by bile salts.

Because the concentration of exogenous arachidonic acid required to stimulate $\mathrm{CL}$ in colonic mucosa was very high, we can not rule out the possibility that these apparent effects of arachidonate were in fact mediated by autooxidation products contained in the preparations employed. In this regard, it is of interest that Bull et al. (43) have recently shown that arachidonate hydroperoxide, but not freshly prepared arachidonate, increases ornithine decarboxylase activity in colonic mucosa. Our studies also do not exclude a role for other products of phospholipid breakdown, most notably diacylglycerol, in the mediation of bile salt-induced increases in reactive oxygen or proliferative activity. Both arachidonate and diacylglycerol have been shown to activate protein kinase $C(42)$. Activation of protein kinase $\mathrm{C}$ in turn has been implicated in the expression of the effects of membrane active agents to trigger the respiratory burst in neutrophils (42). The pathway by which increased generation of reactive oxygen induced by bile salts leads to the subsequent increase in colonic epithelial proliferative activity is also not known. $\mathrm{O}_{2}^{-}$in the presence of transition metal ions can yield $\mathrm{OH} \cdot$. The latter interacts with numerous macromolecules, including nucleic acid, lipids, proteins, and glycoproteins (4). Interaction of $\mathrm{OH}$ - with macromolecules may lead to multiple alterations in cell structure and function, malignant transformation (44), tumor promotion $(32,44)$, cell injury, and mutagenesis (45). Further studies are thus needed to identify the mechanism through which bile salt-induced increases in reactive oxygen are linked to the subsequent stimulation of the proliferative activity of colonic epithelium.

Our results, which support an association between increased generation of reactive oxygen and the stimulation of colonic epithelial proliferative activity, may also have relevance to the increase in proliferative activity seen in inflammatory bowel disease. Previous reports have demonstrated increased accumulation of distal products of both cyclooxygenase and lipoxygenase pathways in inflammatory bowel disease and have suggested that these products might mediate many of the pathophysiologic changes which occur $(46,47)$. By contrast, results of the present study point to reactive oxygen rather than end products of either cyclooxygenase or lipoxygenase activity as mediators of bile saltinduced increases in proliferative activity of colonic mucosa. Similarly, it is possible that reactive oxygen rather than more distal products of arachidonate oxygenation may play a central role in the mediation of the enhancement of epithelial proliferative activity associated with inflammatory bowel disease.

\section{Acknowledgments}

The authors are indebted to Mrs. Myung Hee Jeong for excellent technical assistance and to Ms. Kathy Daum for typing the manuscript.

This work was supported by grant CA 31680 from the National Cancer Institute.

\section{References}

1. DeRubertis, F. R., P. A. Craven, and R. Saito. 1984. Bile salt stimulation of colonic epithelial proliferation: evidence for involvement of lipoxygenase products. J. Clin. Invest. 74:1614-1624.

2. Bull, A. W., L. J. Marnett, E. J. Dawe, and N. D. Nigro. 1983. 
Stimulation of deoxythymidine incorporation in the colon of rats treated intrarectally with bile acids and facts. Carcinogenesis (Lond.). 4:207210.

3. Takano, S., M. Matsushima, E. Erturk, and G. T. Bryan. 1981. Early induction of rat colonic epithelial ornithine and $S$-adenosyl-L-methionine decarboxylase activites by $N$-methyl- $N^{\prime}$-nitro- $N$-nitroso-guanidine by bile salts. Cancer Res. 41:624-628.

4. Slater, T. F. 1984. Review article: free-radical mechanisms in tissue injury. Biochem. J. 222:1-15.

5. McCord, J. M. 1985. Oxygen-derived free radicals in postischemic tissue injury. N. Engl. J. Med. 312:159-163.

6. Lilius, E. M., and S. Laakso. 1982. A sensitive lipoxygenase assay based on chemiluminescence. Anal. Biochem. 119:135-141.

7. Marnett, L. J., P. Wlodawer, and B. Samuelsson. 1974. Light emission during the action of prostaglandin synthesis. Biochem. Biophys. Res. Commun. 60:1286-1294.

8. deAlvare, L. R., K. Goda, and T. Kimura. 1976. Mechanism of superoxide anion scavenging reaction by bis-(salicylato)-copper(II) complex. Biochem. Biophys. Res. Commun. 69:687-694.

9. Burton, K. A. 1956. A study of the conditions and mechanisms of the diphenylamine reaction for the colorimetric estimation of deoxyribonucleic acid. Biochem. J. 62:315-323.

10. Bjerknes, M., and H. Cheung. 1981. Methods for the isolation of intact epithelium from the mouse intestine. Anat. Rec. 199:565-574.

11. Kensler, T. W., and M. A. Trush. 1981. Inhibition of phorbol ester-stimulated chemiluminescence in human polymorphonuclear leukocytes by retinoic acid and 5,6-epoxyretinoic acid. Cancer Res. 41:216222.

12. Clifford, D. P., and J. E. Repine. 1984. Measurement of oxidizing radicals by polymorphonuclear leukocytes. Methods Enzymol. 105:393398.

13. Kakinuma, K., and S. Minakami. 1978. Effects of fatty acids on superoxide radical generation in leukocytes. Biochim. Biophys. Acta. 538:50-59.

14. Sanger, F. 1945. The free amino groups of insulin. Biochem. J. 39:507-515.

15. Neufeld, E. J., and P. W. Majerus. 1983. Arachidonate release and phosphatidic acid turnover in stimulated human platelets. J. Biol. Chem. 258:2461-2467.

16. Maas, R. L., J. Turk, J. A. Oates, and A. R. Brash. 1982. Formation of a novel dihydroxy acid from arachidonic acid by lipoxygenasecatalyzed double oxygenation in rat mononuclear cells and human leukocytes. J. Biol. Chem. 257:7056-7067.

17. Matsushima, M., and G. T. Bryan. 1980. Early induction of mouse urinary bladder ornithine decarboxylase activity by rodent vesical carcinogens. Cancer Res. 40:1897-1901.

18. Sorenson, J. R. J. 1976. Copper chelates as possible active forms of the antiarthritic agents. J. Med. Chem. 19:135-148.

19. Curnette, J. T., J. A. Badwey, J. M. Robinson, M. J. Karnovsky, and M. L. Karnovsky. 1984. Studies of the mechanism of superoxide release from human neutrophils stimulated with arachidonate. J. Biol. Chem. 259:11851-11857.

20. Chance, B., H. Sies, and A. Boveris. 1979. Hydroperoxide metabolism in mammalian organs. Physiol. Rev. 59:527-589.

21. Hille, R., and V. Massey. 1981. Tight binding inhibitors of xanthine oxidase. Pharmacol. Ther. 14:249-263.

22. Ingraham, L. M., R. S. Weening, M. F. Clarke, L. A. Boxer, and R. L. Baehner. 1982. Relation of respiratory burst and arachidonate metabolism during phagocytosis by guinea pig alveolar macrophages. $J$. Lab. Clin. Med. 99:908-916.

23. Fang, W. F., and H. R. Strobel. 1978. The drug and carcinogen metabolism system of rat colon microsomes. Arch. Biochem. Biophys. 186:128-138.

24. Blackwell, G. J., and R. J. Flower. 1978. 1-Phenyl-3-Pyrazolidone. An inhibitor of cyclooxygenase and lipoxygenase pathways in lung and platelets. Prostaglandins. 16:417-425.

25. Sekiya, K., H. Okuda, and S. Arichi. 1982. Selective inhibition of platelet lipoxygenase by esculetin. Biochim. Biophys. Acta. 713:6872.
26. Flower, R. J. 1974. Drugs which inhibit prostaglandin biosynthesis. Pharmacol. Rev. 26:33-67.

27. Marnett, L. J., P. Wlodawer, and B. Samuelsson. 1975. Co-oxygenation of organic substrates by the prostaglandin synthetase of sheep vesicular gland. J. Biol. Chem. 250:8510-8517.

28. Marnett, L. J., P. H. Siedlik, and L. W. M. Fung. 1982. Oxidation of phenidone and BW755C by prostaglandin endoperoxide synthetase. J. Biol. Chem. 257:6957-6964.

29. Henry, R. J., C. Sobel, and J. Kim. 1957. A modified carbonate phosphotungstate method for the determination of uric acid and comparison with the spectrophotometric urinase method. Am. J. Clin. Pathol. 28:152.

30. Roswell, D. F., and E. H. White. 1978. The chemiluminescence of luminol. Methods Enzymol. 57:409-423.

31. Kensler, T. W., D. M. Bush, and W. J. Kozumbo. 1983. Inhibition of tumor promotion by a biomimetic superoxide dismutase. Science (Wash. DC). 221:75-77.

32. Fischer, S. M., and L. M. Adams. 1984. Inhibition of arachidonic acid metabolism inhibits tumor promoter stimulated chemiluminescence in murine keratinocytes. Prostaglandins and Leukotrienes 1984 Meeting Abstracts. 24A.

33. Craven, P. A., R. Saito, and F. R. DeRubertis. 1983. Role of local prostaglandin synthesis in the modulation of proliferative activity of rat colonic epithelium. J. Clin. Invest. 72:1365-1375.

34. DeRubertis, F. R., P. A. Craven, and R. Saito. 1985. Dimethyl prostaglandin $E_{2}$ suppresses the increases in the proliferative activity of rat colonic epithelium induced by indomethacin and aspirin. Gastroenterology. 89:1054-1063.

35. Fischer, S. M., and L. M. Adams. 1985. Suppression of tumor promoter induced chemiluminescence in mouse epidermal cells by several inhibitors of arachidonic acid metabolism. Cancer Res. 45:3130-3136.

36. Fridovich, I. 1975. Superoxide dismutases. Annu. Rev. Biochem. 44:147-164.

37. Bromberg, Y., and E. Pick. 1983. Unsaturated fatty acids as second messengers of superoxide generation by macrophages. Cell. Immunol. 79:242-252.

38. Badway, J. A., J. T. Curnutte, and M. L. Karnovsky. 1981. Cispolyunsaturated fatty acids induce high levels of superoxide production by human neutrophils. J. Biol. Chem. 256:12640-12643.

39. Yoshimoto, S., T. Yoshimoto, and E. Tsubura. 1982. Arachidonic acid-induced chemiluminescence of human polymorphonuclear leukocytes. Biochem. Biophys. Res. Commun. 107:779-784.

40. Smith, R. L., and M. J. Weidemann. 1980. Reactive oxygen production associated with arachidonic acid metabolism by peritoneal macrophages. Biochem. Biophys. Res. Commun. 97:973-980.

41. Badwey, J. A., J. T. Curnutte, J. M. Robinson, C. B. Berde, M. J. Karnovsky, and M. L. Karnovsky. 1984. Effects of free fatty acids on release of superoxide and on change of shape by human neutrophils. Reversibility by albumin. J. Biol. Chem. 259:7870-7877.

42. McPhail, L. C., C. C. Clayton, and R. Snyderman. 1984. A potential second messenger role for unsaturated fatty acids: Activation of $\mathrm{Ca}^{2+}$-dependent protein kinase. Science (Wash. DC). 224:622-624.

43. Bull, A. W., N. D. Nigro, W. A. Golembieski, J. D. Crissman, and L. J. Marnett. 1984. In vivo stimulation of DNA synthesis and induction of ornithine decarboxylase in rat colon by fatty acid hydroperoxides, autooxidation products of unsaturated fatty acids. Cancer Res. 44:4924-4928.

44. Weitzman, S. A., A. B. Weitberg, E. P. Clark, and T. P. Stossel. 1985. Phagocytes as carcinogenes: malignant transformation produced by human neutrophils. Science (Wash. DC). 227:1231-1233.

45. Moody, C. S., and H. M. Hassan. 1982. Mutagenicity of oxygen free radicals. Proc. Natl. Acad. Sci. USA. 79:2855-2859.

46. Sharon, P., and W. F. Stenson. 1984. Enhanced synthesis of leukotriene $\mathrm{B}_{\mathbf{4}}$ by colonic mucosa in inflammatory bowel disease. Gastroenterology. 86:453-460.

47. Ligumsky, M., F. Karmeli, P. Sharon, U. Zor, F. Cohen, and D. Rachmilewitz. 1981. Enhanced thromboxane $A_{2}$ and prostacyclin production by cultured rectal mucosa in ulcerative colitis and its inhibition by steroids and sulfasalazine. Gastroenterology. 81:444-449. 